\title{
The Effect of Candlenut as Mixed Ingredients on the Palm Sugar Quality in the Penyolongan Village of Sangkulirang Districts East Kutai
}

\author{
Liris Lis Komara ${ }^{1 *}$ \\ ${ }^{1}$ Forestry, East Kutai School of Agliculture. Jl. Soekarno-Hatta No. 1, Sangatta, East Kutai, East Kalimantan, \\ Indonesia \\ *Corresponding author. Email: liskomara131415@gmail.com
}

\begin{abstract}
Palm tree (Arenga pinnata Merr) is a non-wood forest product with a big potency to be developed. Palm tree main product resulting from tapping male flower sap can be made to be sugar. This study aims to determine the effect of candlenut as a mixture of ingredients of the palm sugar quality in the Penyolongan Village of Sangkulirang Districts. Lately, palm sugar, besides made from palm trees, is also from coconut plants. The method used in palm sugar processing research is a physical and organoleptic test data methods including texture, color, taste, acceptance, moisture content, and ash content in the Bandung soil laboratory. Based on the study result, the sugar treated by candlenut mixture is very significant in terms of texture, colour and taste compared to the standard sugar that is not treated by candlenut mixture and the acceptance of palm sugar with candlenut treated were very favoured.
\end{abstract}

Keywords: Palm tree, Candlenut, Palm sugar quality

\section{INTRODUCTION}

Palm tree (Arenga pinnata Merr.) is one of the biological wealth of sugar producers in Indonesia [1]. The existence of palm sugar remains sustainable until now because its processing can be done traditionally in the villages [2]. Rural communities were familiar with palm sugar production [3]; the plant spread wide and a very simple processing method for the household scale in the village [4]. The palm plant is a multipurpose plant because almost all of its parts can be utilized. Aren has been cultivated for more than 200 years, especially in Indonesia, for its flour and sugar [5]. Other uses include raw materials of crafts, household appliances and equipment [4]. The potential of aren is important in the forestry sector and a source of raw materials of equipment and buildings [6].

Compared to sugar cane, Palm sugar has several advantages [7]. The characteristics of palm trees are more flexible and stronger than sugarcane. Aren can grow on critical land and flat or sloping land contour and be able to conserve bare land. Palm root has well bind water ability so it can be planted in a dry area. Ecologically, sugar palm is a conservative plant.
Different from sugar cane, Aren is not greedy to take water and nutrients in the soil. Sugar grows by absorbing sunlight. Many people say selling products from palm trees is the same as selling sunlight [8].

Palm sugar production was done traditionally in the countryside [8]. In the processing of juice (Nira) as raw material for palm sugar, one must choose a good palm tree [9]. Palm trees that can be harvested are 7-8 years old trees [6]. If the age of trees is sufficient, palm trees harvested can be carried out evenly. Tapping lasts for 12 hours or is carried out in the morning and evening. Tapping is obtained 6-12 litres of nira each time, depending on the tapped tree [10].

Palm trees development in Indonesia is very prospective. Besides being able to meet domestic consumption needs of products derived from palm trees, it can also increase employment, farmer income, state income and preserve natural resources and the environment. Therefore, to improve palm sugar production quality, it is necessary to research the effect of mixed ingredients on the quality of palm sugar, especially those that include texture, colour, and taste of sugar with candlenut mixture. The purpose of this study 
was to determine the effect of candlenut as a mixture on the

\section{MATERIALS AND METHOD}

\subsection{Study Area}

The research was conducted at the palm sugar craftsmen production house in Penyolongan Village,
Sangkulirang District, East Kutai Regency (Figure 1). Research time is approximately six months. Research at the production house in October 2017, laboratory research conducted at the Vegetable Research Institute of Bandung in January and palm sugar products results from interviews carried out in the community around the production house (general housewives) and students of East Kutai School of Agricultural.

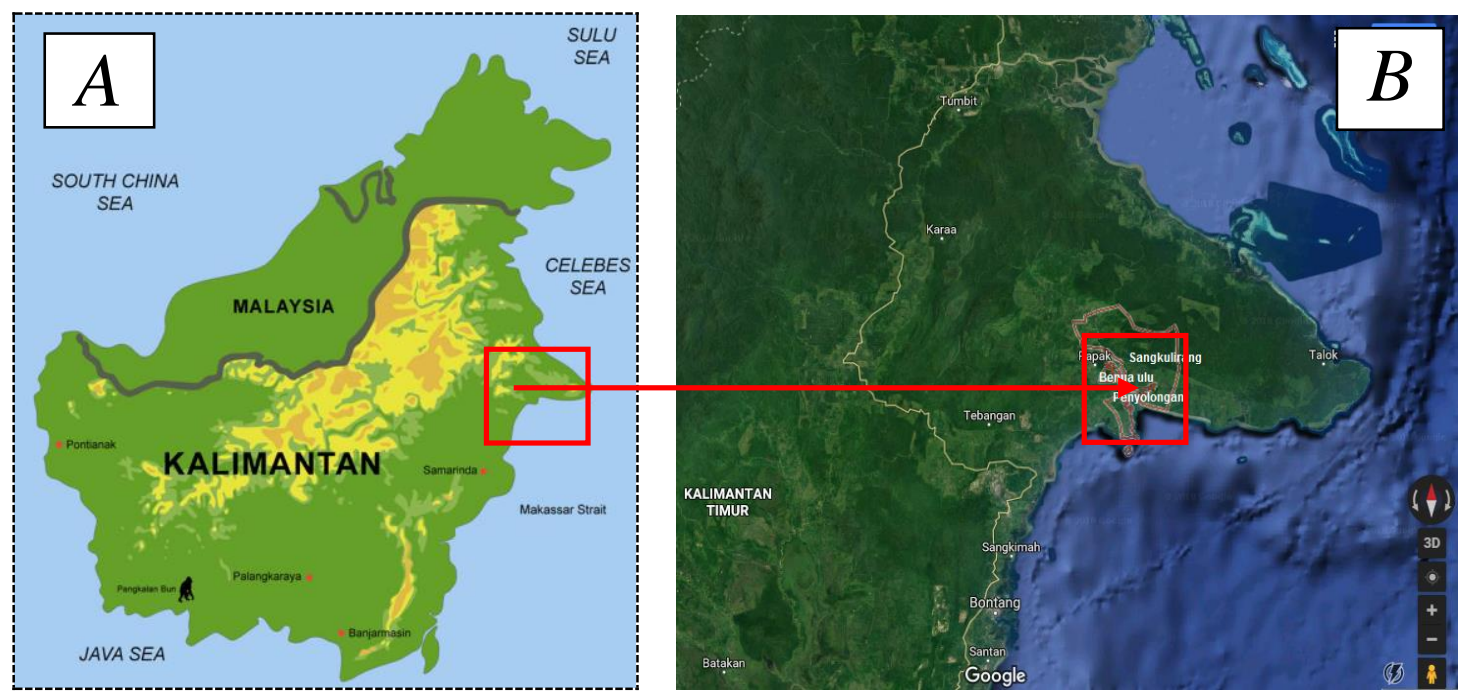

Figure 1 A. Research location in East Kalimantan Province. B. Penyolongan Village Sangkulirang Village at position $0^{\circ} 991742 " \mathrm{~N}$ and $117^{\circ} 971653 \mathrm{E}$

The materials and tools used in this study are as follows: 70 litres of Nira, 300 grams of candlenut (as a mixture). The tools used include the firewood stove, skillet or cauldron to hold the nira, filter to filter dirt and froth of the nira, and print tools to shave the sugar, so that palm sugar has a form, stirring (stirring) to stir the nira.

\subsection{Research Design}

The study was conducted to know the effect of candlenut as a mixture of palm sugar quality before conducting research, first of all, preparing and collecting data from palm sugar craftsmen. The stages of the research activities implementation start from field orientation and observation to retrieve preliminary data, location determination and data processing.

The research was conducted through three stages, namely (1) field observations in the palm sugar craftsmen production house through direct interviews, (2) observations of the palm sugar process and (3) the palm sugar products. After obtaining data from the interview results, the research location was determined in the palm sugar craftsmen production house in Penyolongan Village, Sangkulirang Sub-district, East Kutai Regency as the sampling site. Observations made included the quality of raw materials (palm juice) and product quality (moisture content, ash content three times repetition of palm sugar products and organoleptic tests). Data from survey results and observations are presented in tables and graphs and analyzed descriptively.

Observations and measurements include testing the quality of palm sugar, moisture content, ash content and organoleptic tests. The following are the stages of observation and measurement activities in the field:

\subsubsection{Palm Sugar Quality Testing}

The palm sugar quality testing that was observed included the test of chemical properties in moisture content and ash content and organoleptic test (texture, colour, taste and overall acceptance) using scoring. Panellists/correspondents used in the organoleptic test were 30 housewives and 20 STIPER Forestry students.

\subsubsection{Water Content}

Water content was using the Gravimetric method [11]. The aluminium cup is dried in an oven for 30 minutes, then cooled in a desiccator and weighed. A total of $5 \mathrm{~g}$ of the sample was weighed and then put into an oven at a temperature of $105-110^{\circ} \mathrm{C}$ for 3 hours. After being cooled in the desiccator for 15 minutes, then weighed. After obtaining the first weighing results, then the cup containing the sample is dried again for 30 
minutes, after which it is cooled in a desiccator for 15 minutes then weighed. This second weighing result is compared with the first weighing. If the second weighing reaches a weight reduction not more than $0.001 \mathrm{~g}$ from the first weighing, it is considered constant. However, the weighing is repeated until a weight reduction of two successive weights is obtained. Then the cup and dry sample are weighed.

\subsubsection{Ash Content}

Ash content was determined using the Gravimetric method [12]. $3 \mathrm{~g}$ of palm sugar is weighed in a porcelain cup that has known weight. The cup containing a sample of palm sugar was sprinkled with a Meker burner to not smoke for 1 hour. Then, the cup containing a sample of palm sugar is put into the furnace at a temperature of $600^{\circ} \mathrm{C}$ for 3 hours. The palm sugar sample is weighed again after being cooled in a desiccator.

\subsubsection{Organoleptic Test}

An organoleptic test of the palm sugar quality was done by scoring tests on texture, taste, colour, and overall acceptance. The test results obtained are compared with the quality standards of palm sugar that do not use mixtures that have been determined following SNI 013743.1995, while the organoleptic test form, as stated in Table 1.

\subsection{Data Analysis}

All stages of improving the palm sugar quality through direct observation in the field and analysis of the interview results with palm sugar craftsmen. The discussion of the quality improvement stage used in this study is descriptive analysis. Descriptive analysis was done by describing the observations and interviews results. This method is used to describe various activities or processes taking place when the research is conducted and examine the cause and effect of a particular symptom with relevant calculations or considerations to answer the problems that exist in the research objectives. The quantitative analysis calculates data from the product quality observations results (moisture content and ash content) for three replications of palm sugar products. Qualitative analysis using organoleptic tests to 50 correspondents. Survey and observation results are presented in tables and graphs and then analyzed statistically.

Table 1. Scoring scores on testing for organoleptic palm sugar

\begin{tabular}{llllll}
\hline \multirow{2}{*}{ Test } & \multicolumn{5}{c}{ Score } \\
\cline { 2 - 6 } & \multicolumn{1}{c}{1} & \multicolumn{5}{c}{ 2 } & \multicolumn{1}{c}{ S } & Hard \\
\hline Texture & Soft & A bit soft & Slightly soft & Rather Hard & Yellow \\
Colour & Blackish brown & Brown & Yellowish-brown & Brownish-yellow & Normal \\
Taste & Very bitter & Rather bitter & A little bitter & Bitter & Very like \\
Overall & Very dishlike & Do not like & Rather like & Like & \\
acceptance & & & & & \\
\hline
\end{tabular}

\section{RESULT AND DISCUSSION}

\subsection{Palm Sugar Water Content}

Based on the laboratory research results shows the average palm sugar moisture content using candlenut ingredients is $9.22 \%$ and for standard sugars that do not use mixed ingredients is $9.82 \%$, which means that the standard palm sugar water content is higher than palm sugar using candlenut ingredients, with a difference of $0.6 \%$. Candlenut has unsaturated fat contents; the nature of fat is to deliver heat to evaporate more water [13]. The palm sugar mixed with candlenut shrinks to a lower level than sugar which does not use a mixture of about $0.6 \%$. Moisture is one of the most important parameters in a portion of food because it affects the texture, shelf life, consumer acceptance, and others. The higher the moisture content of an ingredient, the higher the risk of damage to the material due to bacteria, microbes, fungi and chemical processes such as oxidation. In palm sugar, the lower the water content, the harder palm sugar is because the amount of water in the material will greatly affect the stability and quality of the material [10]. Water levels that are too high in palm sugar can cause the hardness level, and palm sugar shelf life would decrease [14].

\subsection{Palm Sugar Ash Content}

Based on the laboratory research results, the average palm sugar ash content using candlenut ingredients is $1.1 \%$, and standard sugar that does not use a mixture of ingredients is $2.0 \%$ sugar ash content with a smaller candlenut mixture of $0.9 \%$ of standard sugar. The oil content in candlenut mixed with palm sugar does not affect the ash content because candlenut is an organic material [13]. Ash content is an important parameter in 
determining the quality of palm sugar [14]. The ash content and composition depend on the raw material type and how it is treated. The increase in ash content of palm sugar is due to increased inorganic mineral compounds in the product. It is influenced by the presence of sodium in sodium bicarbonate [15].
Minerals in a material can be in the form of two kinds of salt, namely organic and inorganic. Included in organic salts such as malic acid salts, oxalates, acetates, pectates. In contrast, inorganic salts include phosphate, carbonate, chloride, sulfate and nitrate salts.

Table 2. Scoring scores on testing for organoleptic palm sugar

\begin{tabular}{|c|c|c|}
\hline Palm sugar sample & Water content & Ash content \\
\hline A (Standard) & 9,82 & 2,0 \\
\hline B (Candlenut) & 9,22 & 1,1 \\
\hline $\begin{array}{l}\text { 3.3. Organoleptic Test of Palm Sugar } \\
\text { An organoleptic test is a test system of food objects } \\
\text { that uses the human senses, ranging from sight, sense of } \\
\text { smell, taste, and sense of touch. This organoleptic test is } \\
\text { hedonic (test of preference) of } 50 \text { correspondents. The }\end{array}$ & \multicolumn{2}{|c|}{$\begin{array}{l}\text { otherwise (dislike). Preferred levels are referred to as } \\
\text { hedonic scales with a scale of } 1-5 \text {. With this, numerical } \\
\text { data can be analyzed through statistical data [16]. In this } \\
\text { study, the sample parameters carried out by the hedonic } \\
\text { test included parameters of texture, colour and taste of } \\
\text { palm sugar in general. }\end{array}$} \\
\hline
\end{tabular}

Table 3. Analysis of Variance of Palm Sugar Organoleptic Test Results

\begin{tabular}{lccc}
\hline & & & \multicolumn{2}{c}{ F-table } \\
\cline { 3 - 4 } Variance & F-count & $5 \%$ & $1 \%$ \\
\hline Texture & & 3.18 & 5.06 \\
Color & 1047.69 & 3.18 & 5.06 \\
Taste & 228.94 & 3.18 & 5.06 \\
Overall acceptance & 1045.55 & 3.18 & 5.06 \\
\hline
\end{tabular}

\subsubsection{Texture}

Texture in palm sugar determines the palm sugar density level: the palm sugar softness or hardness. Based on the organoleptic test results for standard sugar texture with 50 correspondents, $68 \%$ stated soft, $16 \%$ a bit soft, and $16 \%$ slightly soft. For the palm sugar texture with candlenut from 50 correspondent, $4 \%$ stated rather hard and $96 \%$ hard. From the organoleptic testing results with 50 correspondents, correspondents prefer candlenut palm sugar because it has a more dense and hard texture, so it is not easy to break or melt. Compared to the texture of palm sugar with standard processing procedures, most of them state the sugar's texture is soft. The count F test is presented in Table 3. Based on the processing statistical variables results, the texture of palm sugar is stated count F 1047.69 greater than $\mathrm{F}$ table on a scale of $5 \%$ (3.18) and 1\% (5.06) which means there is a very real difference in the texture of palm sugar after adding candlenut that is the palm sugar with standard processing which originally had a soft texture to be harder after adding candlenut.

\subsubsection{Colour}

The colour in palm sugar is the distinguishing level between standard sugar and sugar mixed with candlenut. From the organoleptic tests results with 50 correspondents for the palm sugar standard colour $2 \%$ stated brown, $80 \%$ said it was yellowish-brown, $16 \%$ said it was brownish yellow, and $2 \%$ said it was yellow. For candlenut sugar, the colour of palm sugar mixed with candlenut with 50 correspondents stated that $38 \%$ said it was blackish-brown, $60 \%$ brown, $2 \%$ yellowish brown. For the organoleptic testing results with 50 correspondents, correspondents prefer palm sugar with candlenut because the colour is more concentrated, while sugar with standard processing has a paler colour. The count F test is presented in Table 3. Based on the statistical variables processing results for the colour of palm sugar stated $\mathrm{F}$ count $=228.94$ greater than $\mathrm{F}$ table on a $5 \%$ scale $(=3.18)$ and $1 \%(=5.06)$, which means 
there is a very real difference in the colour of palm sugar after adding candlenut. The colour of palm sugar products originally had a yellowish-brown colour and after adding hazelnut had a brown colour.

\subsubsection{Taste}

The taste in palm sugar determines the normal or bitter of palm sugar that is produced. Based on the organoleptic test results for the taste of standard palm sugar with 50 correspondents, $74 \%$ were rather bitter, $24 \%$ were a little bitter, and $2 \%$ expressed bitter. For the taste of palm sugar, 50 correspondents said $2 \%$ were rather bitter, $98 \%$ normal. From the organoleptic testing results with 50 correspondents, correspondents prefer palm sugar mixed with candlenut because it has a normal taste, so the sugar feels more legitimate than standard palm sugar, which most correspondents say the taste has a slightly bitter or somewhat bitter taste. The count $\mathrm{F}$ test is presented in Table 3. Based on the processing statistical variables, the taste of palm sugar is stated count $\mathrm{F}=1045.55$ is greater than $\mathrm{F}$ table on a $5 \%$ scale $(=3.18)$ and $1 \%(=5.06)$, which means there is a very real difference in the palm sugar taste after adding candlenut. The taste of palm sugar products originally had a slightly bitter or slightly bitter taste after adding candlenut flavour became normal.

\subsubsection{Overall Acceptance}

Overall acceptance compared to the preference between standard sugars and palm sugar mixed with candlenut to determine which sugar is more accepted in the community. Based on the organoleptic test results for the overall acceptance of standard palm sugar, with 50 correspondents, $10 \%$ said they were very disliked, $74 \%$ did not like it, and $16 \%$ were rather like it. While the overall acceptance of candlenut palm sugar with 50 correspondents, $2 \%$ said it was rather like, $18 \%$ liked, and $80 \%$ liked. From the organoleptic testing results with 50 correspondents, correspondents prefer and accept palm sugar with candlenut in terms of the colour texture and taste of palm sugar compared to palm sugar with the standard because it has a soft texture, a pale colour and a rather bitter or somewhat bitter taste. The count $\mathrm{F}$ test is presented in Table 3.

Based on the processing statistical variables results for palm sugar preference, count $\mathrm{F}=626.74$ is greater than $\mathrm{F}$ table on a $5 \%$ scale $(=3.18)$ and $1 \%(=5.06)$, which means there are very real differences in the level of preference for palm sugar after adding candlenut. Correspondent organoleptic test results prefer palm sugar with candlenut because it is superior in terms of texture, taste, and colour is also more concentrated, and overall acceptance is preferred.

\section{CONCLUSION}

The conclusion from the observations and testing results is the addition of candlenut in the palm sugar production can help produce palm sugar with a better parameter quality in its texture, colour, taste, and preference because the candlenut help reduces water content in palm sugar that can make the fungus difficult to grow.

\section{REFERENCES}

[1] Bahrawi, Sumarno, Prospects of Palm Sugar Agribusiness Development, Case Study in Patemon Village, Kec. Bungatan District. Situbondo, Online Journal of Situbondo Abdurahman Saleh, 2015.

[2] R.S. Hidayat, Y. Rusman, M. Ramdan, Analysis of the Arenga pinnata Sugar Channel Marketing in Capar Village, Brebes Regency, Faculty of Agriculture, Galuh University and Faculty of Agriculture, Padjadjaran University, 2016.

[3] R.R.H Hau, M.M.P. Aji, Sulhadi, S.K. Hau, S.D. Talu, Palm Sugar Strong Value Press, Proceedings of the National Physics Seminar 5. E SNF Journal, 2016.

[4] M. Lempang, Palm Trees and its production benefits EBONI Technical Info, 1(9), 2012, pp. 37 54.

[5] R.D. Nurdina, Palm sugar potential (Arenga pinnata, MERR) in West Java (http://disbun.jabarprov.go.id/index.php/artikel/det ailartikel/10) accessed in November 2017.

[6] Baharudin, Taskirawati, Non Timber Forest Product, Forestry Faculty, Universitas Hasanuddin, 2009.

[7] D. Nursafuan, Ersan, D. Supriyatdi, Liquid Palm Sugar with Chalk Control and Evaporation Temperature, Journal of Agro Industri Perkebunan, 2(4), 2016, pp. 79-87.

[8] Anonymous, Palm Sugar Area Decrease East Kutai Province, Plantation Departement, 2011.

[9] W.R. Hartari, Quality Survey (Ash Content, Insoluble Solids) and Brown Sugar Products Safety (Borax content) in Bandar Lampung City Market Thesis Faculty of Agriculture Bandar Lampung University, 2016.

[10] M.T. Lasut, Palm Sugar Processing Module Faculty of Agriculture Sam Ratulangi University Manado, 2012.

[11] J. Pontoh J, Determination of Sucrose Content in Palm Sugar with Enzymatic Method, Chem. Prog., 1(6), 2013. 
[12] Anonymous, Official Methods of Analysis, AOAC Arlington Association of Official Analytical Chemist (AOAC) 1995-2005, 1995.

[13] S. Hermawati, L. Purnavita, Description of temperature and adsorption time on the chemical physical properties of used cooking oil as a purification result using sugar palm starch pulp adsorbents in bentonite, Momentum, 10(2), 2014, pp. 31-41

[14] S.R. Dewi, D.M. Maharani, R. Yulianingsih, Y. Sugiarto, D.W. Indriani, Pengaruh Penambahan Natrium Metabisulfit dan Suhu Pemasakan dengan Teknologi Vakum terhadap Gula Merah, Fakultas dengan Pertanian Universitas Brawijaya Malang, 2014.

[15] Making Coconut Palm Sugar, Study of the pH of the Sugar and Sodium Bicarbonate Concentration, Journal of Food and Agroindustry, 4(1).

[16] Anonymous, Organoleptic Test, Food Technology Study Programe Semarang Muhammadiyah University, 2013. 